\title{
Ammonium Thiosulfate Ecological Viable Alternative to Replace Sodium Cyanide in Gold and Silver Dissolution
} Ores

\author{
María del Carmen Hernández ${ }^{1}$, María del Carmen Avitia ${ }^{1}$, Heriberto Peña ${ }^{1}$, Irma Leticia Gonzalez ${ }^{2}$, Nancy \\ Verónica Torres ${ }^{3}$, Abdiel Rosaldo Félix ${ }^{3}$, Luis Miguel Rodríguez ${ }^{1}$ and Laura Bibiana Hernández ${ }^{4}$ \\ 1. Department of Chemical and Biochemical Engineering, Technological Institute of Parral, Chihuahua 33850, Mexico \\ 2. Department of Economic Administrative Department, Technological Institute of Parral, Chihuahua 33850, Mexico \\ 3. Department of Industrial Engineering, Technological Institute of Parral, Chihuahua 33850, Mexico \\ 4. Engineering and Independent Consultant, Palma Triangular 108, San José de Pozo Bravo, Aguascalientes 20126, México
}

\begin{abstract}
The southern region of the state of Chihuahua is mining by origin, as this has been proved ghost towns of Minas Nuevas, it is also called Villa Escobedo, Emerald and Blue. Minerals are nonrenewable resources. There are only reserves and waste deposited in tailings ponds of low-rade precious metals (gold and silver). A conventional method for recovering gold and silver ore is low-grade cyanidation and the solvent consider toxic and highly dangerous for the flora, fauna, humans and the environment. The mechanism of cyanide poisoning is inhibition of cytochrome oxidase - an enzyme needed for cell respiration. Without compromising efficiency, sensitivity and cost of the process, the toxic solvent is replaced by a less aggressive one, which helps the environment, public and occupational health. $\left(\mathrm{NH}_{4}\right)_{2} \mathrm{~S}_{2} \mathrm{O}_{3}$ has no appreciable damage to conservative amounts, is a selective aqueous solvent for leaching gold and silver, easy to get and manipulate. This work is done in the Technological Institute of Parral in a low-grade ore from the southern region of the state of Chihuahua. This document has been enriched presented in the IMEC 2014, with the increase of series V and VI.
\end{abstract}

Key words: Leaching, cyanide, ammonium thiosulfate.

\section{Introduction}

The mining industry in the extraction of gold and silver has been using sodium cyanide $(\mathrm{NaCN})$ in production processes for centuries. The $\mathrm{NaCN}$ is essential in the modern world, but its effects on health and the environmen thave led to the recent publicreaction to the use of $\mathrm{NaCN}$.

The $\mathrm{NaCN}$ is one of the few chemical reagents, which dissolve the gold and silver in water and has been used in extracting them by an established technology since 1887 . There are two general ways to leach gold and silver from an ore by $\mathrm{NaCN}$ : leaching tank and percolation leaching. Tank leaching is the

Corresponding author: María del Carmen Hernández, master, main research field: metallurgy. conventional method by which auriferous ore is crushed and ground to reduce it to less than 1 millimeterin diameter and is leached with acy anide solution typically between $0.01 \%$ and $0.05 \%$. Safety measures in handling such salts are meticulous. Formal policies of companies that manufacture cyanide ensure that their product is only sold to companies that have the capacity and commitment to protect workers, the public and the environment. They hire selected carriers with safety records compatible with the rules of carriage manufacturers. Mining companies store the sodium cyanide in secure areas whit controlled environment like dry, fresh, dark and airy, also, the boxes are stacked over impermeable floors, usually built with concrete adequate to contain any unlikely spillover. 
Training programs are required for all employees who work with or near the cyanide. Companies have security plans and material handling in which the responsibilities to employees who control the management and use of cyanide from its arrival at the mine site and throughout the metallurgical process are assigned. Feature monitors gas area suitable protective clothing, autonomous breathing stations and first aid equipped with eyewash and showers. Toxic to 18.36 ppm causes mild symptoms after several hours, 135 $\mathrm{ppm}$ is fatal after 30 minutes and $270 \mathrm{ppm}$ is immediately fatal [1]. The mechanism by which the cyanide causes poisoning is the inhibition of the oxidase cytochrome system, also other enzymatic systems are affected too much, but to a lesser grade.

The current problematic is the replacement of sodium cyanide by ammonium thiosulfate, minimizing the toxic risk to the environment including the public and occupational health. Ammonium thiosulfate does not cause appreciable damage using conservative quantities in addition it has the benefit of being an aqueous solvent for leaching gold and silver, which selectively dissolves with high probabilities of replacing cyanide at low cost and with the conventional infrastructure.

Reaction leaching of precious metals with ammonium thiosulfate: add copper with thiosulfate and ammonia produce that the gold is dissolved quickly in comparison with the process that uses cyanide. The gold leaching is produced according to the reaction in Eq. (1) [2]:

$$
\begin{aligned}
& \mathrm{Au}+5 \mathrm{~S}_{2} \mathrm{O}_{3}^{2-}+\mathrm{Cu}\left(\mathrm{NH}_{3}\right)_{4}^{2+} \leftrightarrow \\
& \mathrm{Au}\left(\mathrm{S}_{2} \mathrm{O}_{3}\right)_{2}^{3-}+4 \mathrm{NH}_{3}+\mathrm{Cu}\left(\mathrm{S}_{2} \mathrm{O}_{3}\right)_{2}^{5-}
\end{aligned}
$$

The metallic gold is oxidized to $\mathrm{Au}^{+}$by effect of the copper complex $\mathrm{Cu}\left(\mathrm{NH}_{3}\right)_{4}{ }^{2+}$, then the thiosulfate ions complexed the $\mathrm{Au}^{+}$formed to integrate the complex $\mathrm{Au}\left(\mathrm{S}_{2} \mathrm{O}_{3}\right)_{2}{ }^{3-}$. The $\mathrm{Cu}\left(\mathrm{NH}_{3}\right)_{4}{ }^{2+}\left(\mathrm{Cu}^{2+}\right)$ complex in presence of $\mathrm{S}_{2} \mathrm{O}_{3}{ }^{2-}$ form the $\mathrm{Cu}\left(\mathrm{S}_{2} \mathrm{O}_{3}\right)_{2}{ }^{5-}$ complex according to the reaction in Eq. (2):

$$
\begin{gathered}
\mathrm{Cu}\left(\mathrm{NH}_{3}\right)_{4}{ }^{2+}+3 \mathrm{~S}_{2} \mathrm{O}_{3}^{2-}+1 e \leftrightarrow \\
\mathrm{Cu}\left(\mathrm{S}_{2} \mathrm{O}_{3}\right)_{2}{ }^{5-}+4 \mathrm{NH}_{3}
\end{gathered}
$$

\section{Experimental Work}

This paper emerges from an academic commitment to provide safe procedures to protect workers in the mining industry from the public and the environment.

It is performed in the laboratories of the Technological Institute of Parral, mainly in the metallurgy laboratory, which has equipment for mechanical preparation consisting of 2 crushers jaw, 2 cone crushers, pulverize and set of meshes from 45 U.S. (0.038 inches) to 325 U.S. (0.0017 inches) and Ro-Tap for particle size control. The study conduct the whirling in a roller table using amber bottles with acid (leaching capacity $1,000 \mathrm{~mL}$ ) at 56 revolutions per minute.

The research used a sample of 64 kilograms which was prepared $100 \%$ passing by the mesh number 10 , the granulometry of the sample is determined, including the specific gravity and the assay of gold and silver. The constants to determine the process of cyanide were probable consumption of lime, grinding, protector alkali, pulp dilution, cyanide concentration and stirring time. It was taken as basis of the procedure to determine the parameters in the process of cyanidation developed by David, C. C. [3], which method consist in determining one variable at time. The constants show in Table 1.

To control the cyanidation process, valuations are made of cyanide and free calcium oxide with silver

Table 1 Constants determined for cyanidation.

\begin{tabular}{llllllll}
\hline Probable consumption of lime & Griding (mesh) & $\begin{array}{l}\text { Alkali } \\
\text { protector } \\
(\%) \mathrm{CaO}\end{array}$ & $\begin{array}{l}\text { Dilution } \\
\text { water: } \\
\text { ore }\end{array}$ & \multicolumn{2}{c}{$\begin{array}{c}\text { Cyanide } \\
\text { concentration }\end{array}$} & $\begin{array}{l}\text { Time } \\
\text { stirring } \\
(\%) \mathrm{CN}\end{array}$ & $\begin{array}{l}\text { R/t } \\
\text { Recovery } \\
(\%)\end{array}$ \\
\hline $0.026 \mathrm{~g} / \mathrm{T}$ & $100 \% \mathrm{a}-100$ & 0.10 & $2: 1$ & 0.15 & 1,060 & 48 & 37.2 \\
\hline
\end{tabular}




\section{Ammonium Thiosulfate Ecological Viable Alternative to Replace Sodium Cyanide in Gold and Silver Dissolution Ores}

nitrate and oxalic acid, respectively, using phenolphthalein as an indicator in the case of $\mathrm{CaO}$. To facilitate the process, the solutions were precipitated using zinc powder and lead acetate, melting the precipitated sample through a basic flux mixture.

Based on the results, cyanidation proceeded to design tests for ammonium thiosulfate. To which some patents and related studies were reviewed sodium thiosulfate [4-10].

The ammonium thiosulfate is used in solution with a concentration of $56 \%$, yellow and with a density of 1.32 grams per cubic centimeter. For the first series,
$200 \mathrm{~g}$ of sample were used. The activator of copper sulfate was used in a 1:1 with ammonium thiosulfate. Dilution pulp was 2:1 (Table 2).

In the second series, the influence of $\mathrm{pH}$ was considered, the concentration of ammonium thiosulfate and copper sulfate maintain constant leaching time 3 hours (Table 3 ).

In the third series of tests, it is considered the influence of the agitation, the particle size and time, keeping the $\mathrm{pH}$ constant at 10 , ammonium hydroxide and the sample at 200 grams and dilution of $2: 1$ per bottle (Table 4 ).

Table 2 Test conditions ammonium thiosulfate SERIE I.

\begin{tabular}{lcllllll}
\hline Number & $\mathrm{pH}$ & $\mathrm{NH}_{4} \mathrm{OH}(\mathrm{mL})$ & $\begin{array}{l}\left(\mathrm{NH}_{4}\right)_{2} \mathrm{~S}_{2} \mathrm{O}_{3} \\
(\mathrm{~mL})\end{array}$ & $\mathrm{CuSO}_{4} 3 \%(\mathrm{~mL})$ & Time $(\mathrm{h})$ & \multicolumn{2}{c}{$\operatorname{Recovery~(\% )~}$} \\
\hline 1 & 10 & 160 & 80 & 80 & 48 & 95 & $\mathrm{Ag}$ \\
2 & 10 & 160 & 80 & 80 & 3 & 84 & 83 \\
3 & 10 & 160 & 80 & 80 & 3 & 80 & 59 \\
4 & 8.5 & 80 & 40 & 40 & 1.5 & 60 & 69 \\
\hline
\end{tabular}

Table 3 Test conditions ammonium thiosulfate SERIES II.

\begin{tabular}{|c|c|c|c|c|c|c|c|}
\hline \multirow{2}{*}{ Number } & \multirow{2}{*}{ Sample (g) } & \multirow{2}{*}{$\mathrm{pH}$} & \multirow{2}{*}{$\mathrm{NH}_{4} \mathrm{OH}(\mathrm{mL})$} & \multirow{2}{*}{$\begin{array}{l}\left(\mathrm{NH}_{4}\right)_{2} \mathrm{~S}_{2} \mathrm{O}_{3} \\
(\mathrm{~mL})\end{array}$} & \multirow{2}{*}{$\mathrm{CuSO}_{4} 3 \%(\mathrm{~mL})$} & \multicolumn{2}{|c|}{ Recovery (\%) } \\
\hline & & & & & & $\mathrm{Au}$ & $\mathrm{Ag}$ \\
\hline 1 & 200 & Nat* & - & 80 & 80 & 99 & 4 \\
\hline 2 & 200 & 10 & 10 & 40 & 40 & 99 & - \\
\hline 3 & 200 & 10 & 10 & $\begin{array}{l}10 \\
10 \% \text { weight }\end{array}$ & 10 & 100 & 34 \\
\hline 4 & 200 & 10 & 10 & $\begin{array}{l}11.7 \\
10 \% \text { vol. }\end{array}$ & 11.7 & 99 & 35 \\
\hline 5 & 200 & Nat* & - & $\begin{array}{l}11.7 \\
10 \% \text { weight }\end{array}$ & 11.7 & 100 & 32 \\
\hline 6 & 200 & Nat* & - & 80 & - & 100 & 33 \\
\hline
\end{tabular}

*Natural, without addition of reagent $\mathrm{pH}$ modifier.

Table 4 Test conditions of ammoniumthio sulfate SERIES III.

\begin{tabular}{|c|c|c|c|c|c|c|c|}
\hline \multirow{2}{*}{ Number } & \multirow{2}{*}{ Stirring } & \multirow{2}{*}{$\begin{array}{l}\text { Particle size } \\
\text { (mesh) }\end{array}$} & \multirow{2}{*}{$\begin{array}{l}\left(\mathrm{NH}_{4}\right)_{2} \mathrm{~S}_{2} \mathrm{O}_{3} \\
(\mathrm{~mL})\end{array}$} & \multirow{2}{*}{$\mathrm{CuSO}_{4} 3 \%(\mathrm{~mL})$} & \multirow{2}{*}{ Time (h) } & \multicolumn{2}{|c|}{ Recovery (\%) } \\
\hline & & & & & & $\mathrm{Au}$ & $\mathrm{Ag}$ \\
\hline 1 & With & -100 & $10,10 \%$ weight & 10 & 6 & 99 & 32 \\
\hline 2 & With & -100 & $10,10 \%$ weight & - & 6 & 100 & 36 \\
\hline 3 & With & -100 & $10,10 \%$ weight & 10 & 48 & 100 & 33 \\
\hline 4 & With & -100 & $10,10 \%$ weight & 10 & 12 & 100 & 22 \\
\hline 5 & Without & -100 & $10,10 \%$ weight & 10 & 24 & 100 & 38 \\
\hline 6 & Without & -100 & $10,10 \%$ weight & 10 & 48 & 100 & 32 \\
\hline 7 & With & -35 & $10,10 \%$ weight & 10 & 24 & 100 & 37 \\
\hline 8 & With & -35 & 80 & 80 & 24 & 99 & 58 \\
\hline
\end{tabular}


The fourth series was time constant to 24 hours. The bottles 5 and 6 correspond to sample Band Crespectively for the behavior of ammonium thiosulf at ehigher gradeores (Table 5).

In the fifth series of leach tests, they were conducted for samples A, B and C. The conditions were absence of oxygen, aqueous dilution 2:1 and 48 hours of treatment as shown in Table 6 .

The sixth test series includes the three samples A, B and $\mathrm{C}$ in Table 7 shows that the test conditions are presented, $\mathrm{pH} 9$, dilution of 2:1 and the leaching time was variable to establish one where greater solution is obtained.

\section{Results and Discussion}

From the results, it has laws observable head in Table 8 . The sample for the study prepared $100 \%$ passing 10 mesh US. The particle size of the sample prepared for the cyanidation $100 \%$ passing the 35 mesh US. The particle size used in determining cyanidation

Table 5 Test conditions ammonium thiosulfate SERIES IV.

\begin{tabular}{|c|c|c|c|c|c|c|c|}
\hline \multirow{2}{*}{ Number } & \multirow{2}{*}{$\begin{array}{l}\text { Particle size } \\
\text { (mesh) }\end{array}$} & \multirow{2}{*}{$\mathrm{pH}$} & \multirow{2}{*}{$\mathrm{NH}_{4} \mathrm{OH}(\mathrm{mL})$} & \multirow{2}{*}{$\begin{array}{l}\left(\mathrm{NH}_{4}\right)_{2} \mathrm{~S}_{2} \mathrm{O}_{3} \\
(\mathrm{~mL})\end{array}$} & \multirow{2}{*}{$\mathrm{CuSO}_{4} 3 \%(\mathrm{~mL})$} & \multicolumn{2}{|c|}{ Recovery (\%) } \\
\hline & & & & & & $\mathrm{Au}$ & $\mathrm{Ag}$ \\
\hline 1 & -35 & $\begin{array}{l}10 \\
\mathrm{Ca}(\mathrm{OH})_{2}\end{array}$ & - & 80 & 80 & 75.6 & 98.2 \\
\hline 2 & -100 & 7 & 40 & 80 & $80 *$ & 91.2 & 98.2 \\
\hline 3 & -100 & 7 & 10 & 40 & 40 & 87.6 & 98.2 \\
\hline 4 & -100 & 7 & 10 & 40 & 20 & 87.0 & 98.2 \\
\hline 5 & -35 & - & 40 & 80 & 80 & 95.1 & 89.3 \\
\hline 6 & -35 & - & 40 & 80 & 80 & 12.5 & 69.3 \\
\hline
\end{tabular}

*This test is performed with $\mathrm{CuSO}_{4} 1 \%$.

Table 6 Test conditions ammonium thiosulfate SERIES V.

\begin{tabular}{llllllll}
\hline Number & $\begin{array}{l}\text { Particle size } \\
(\mathrm{m} e s h)\end{array}$ & $\mathrm{pH}$ & $\mathrm{NH}_{4} \mathrm{OH}(\mathrm{mL})$ & $\begin{array}{l}\mathrm{NH}_{4}\left(\mathrm{~S}_{2} \mathrm{O}_{3}\right)_{2} \\
100 \%(\mathrm{~mL})\end{array}$ & $\mathrm{CuSO}_{4} 3 \%(\mathrm{~mL})$ & \multicolumn{2}{c}{$\mathrm{Recovery}(\%)$} \\
\hline 1 & -100 & 9 & 40 & 80 & 80 & 100 & $\mathrm{Ag}$ \\
2 & -35 & 9 & 40 & 80 & 80 & 100 & 84 \\
3 & -35 & 9 & 40 & 80 & 80 & 66 & 66 \\
\hline
\end{tabular}

Table 7 Test conditions ammonium thiosulfate SERIES VI.

\begin{tabular}{|c|c|c|c|c|c|c|}
\hline \multirow{2}{*}{ Number } & \multirow{2}{*}{$\begin{array}{l}\text { Particle size } \\
\text { (mesh) }\end{array}$} & \multirow{2}{*}{$\begin{array}{l}\mathrm{NH}_{4}\left(\mathrm{~S}_{2} \mathrm{O}_{3}\right)_{2} \\
(\mathrm{~mL})\end{array}$} & \multirow{2}{*}{$\mathrm{CuSO}_{4} 3 \%(\mathrm{~mL})$} & \multirow{2}{*}{$\begin{array}{l}\text { Time } \\
\text { (h) }\end{array}$} & \multicolumn{2}{|c|}{ Recovery (\%) } \\
\hline & & & & & $\mathrm{Au}$ & $\mathrm{Ag}$ \\
\hline $1 \mathrm{~A}$ & -100 & 80 & 80 & 4 & 100 & 100 \\
\hline 1B & -35 & 80 & 80 & 5 & 100 & 100 \\
\hline $1 \mathrm{C}$ & -35 & 80 & 80 & 7 & 100 & 100 \\
\hline $2 \mathrm{~A}$ & -100 & 80 & 80 & 8 & 100 & 100 \\
\hline $2 \mathrm{~B}$ & -35 & 80 & 80 & 3 & 89 & 77 \\
\hline $2 \mathrm{C}$ & -35 & 80 & 80 & 4 & 100 & 78 \\
\hline $3 \mathrm{~A}$ & -100 & 80 & 80 & 5 & 85 & 79 \\
\hline 3B & -35 & 80 & 80 & 6 & 77 & 81 \\
\hline $3 \mathrm{C}$ & -35 & 80 & 80 & 24 & 91 & 88 \\
\hline $4 \mathrm{~A}$ & -100 & 80 & 80 & 3 & 87 & 63 \\
\hline $4 \mathrm{~B}$ & -35 & 80 & 80 & 4 & 83 & 60 \\
\hline $4 \mathrm{C}$ & -35 & 80 & 80 & 5 & $* *$ & 63 \\
\hline $5 \mathrm{~B}$ & -35 & 80 & 80 & 6 & 83 & 68 \\
\hline $5 \mathrm{C}$ & -35 & 80 & 80 & 24 & 71 & 66 \\
\hline
\end{tabular}

\footnotetext{
* Inconsistent, higher than the value of his head.
} 
Table 8 Head laws samples investigated.

\begin{tabular}{llllllllll}
\hline \multirow{2}{*}{ Sample } & \multicolumn{7}{c}{ Assay $(\mathrm{g} / \mathrm{T})$} & \multicolumn{7}{c}{ Laws (\%) } \\
\cline { 2 - 12 } & $\mathrm{Au}$ & $\mathrm{Ag}$ & $\mathrm{Al}$ & $\mathrm{As}$ & $\mathrm{Cu}$ & $\mathrm{Fe}$ & $\mathrm{Mn}$ & $\mathrm{Sb}$ & $\mathrm{Zn}$ \\
\hline $\mathrm{A}$ & 1.91 & 55.6 & 3.67 & 0.01 & 0.009 & 2.62 & 0.01 & 0.004 & 0.01 \\
$\mathrm{~B}$ & 7.83 & 131 & - & 0.01 & 0.008 & 4.31 & - & 0.002 & 0.02 \\
$\mathrm{C}$ & 0.08 & 238 & - & 0.03 & 0.029 & 4.81 & - & 0.018 & 0.06 \\
\hline
\end{tabular}

Table 9 Sieve Analysis Sample.

\begin{tabular}{|c|c|c|c|c|c|c|c|c|c|c|}
\hline \multirow{3}{*}{$\begin{array}{l}\text { Particle size } \\
\text { (mesh) }\end{array}$} & \multicolumn{3}{|c|}{$100 \%-10$ mesh } & \multicolumn{3}{|c|}{$100 \%-35$ mesh } & \multicolumn{4}{|c|}{$100 \%-100$ mesh } \\
\hline & \multicolumn{2}{|c|}{ weight (\%) } & Cumulative & \multirow[t]{2}{*}{$\begin{array}{l}\text { weight } \\
(\%)\end{array}$} & \multicolumn{2}{|c|}{ Cumulative } & \multirow[t]{2}{*}{ Mesh } & \multirow[t]{2}{*}{$\begin{array}{l}\text { weight } \\
(\%)\end{array}$} & \multicolumn{2}{|c|}{ Cumulative } \\
\hline & & + & - & & + & - & & & + & - \\
\hline$-10+35$ & 58.36 & 58.36 & 41.64 & & & & & & & \\
\hline$-35+45$ & 7.04 & 65.40 & 34.60 & 13.44 & 13.44 & 86.56 & & & & \\
\hline$-45+70$ & 7.18 & 72.58 & 27.42 & 20.01 & 33.45 & 66.55 & $-100+140$ & 13.99 & 13.99 & 86.01 \\
\hline$-70+100$ & 3.74 & 76.32 & 23.68 & 11.20 & 44.65 & 55.35 & $-140+200$ & 17.25 & 31.24 & 68.76 \\
\hline$-100+140$ & 3.00 & 79.32 & 20.68 & 7.18 & 51.83 & 48.17 & $-200+270$ & 11.59 & 42.83 & 57.17 \\
\hline$-140+200$ & 2.82 & 82.14 & 17.86 & 7.20 & 59.03 & 40.97 & $-270+325$ & 2.50 & 45.33 & 54.67 \\
\hline \multirow[t]{2}{*}{-200} & 17.86 & 100.00 & 0.00 & 40.97 & & 0.00 & -325 & 54.67 & 100.00 & 0.00 \\
\hline & 100.00 & & & 100.00 & & & & 100.0 & & \\
\hline
\end{tabular}

which is constant $100 \%$ to less $100 \%$ mesh was made to US (Table 9).

The first series (Table 2) shows that the leaching time is decisive for the dissolution of gold. On the three samples at the 48 hours, the recovery only increased $6 \%$, from one and a half to three hours, increased $16 \%$. For this reason, in the second set time (Table 3), it remains at three hours and six tests behavior is observed when changing the $\mathrm{pH}$ to 10 while natural $\mathrm{pH}$ being 7 , the sample fed the ammonium thiosulfate in different concentrations trying to find a similar procedure in the control of solutions used in the cyanidation. The results show a complete dissolution in ones and almost complete in other tests.

From these results, the question arises about the particle size and the third experimental series is prepared (Table 4), where the agitation and static leaching tests are included, with a particle size of $100 \%$ passing through the 100 mesh and $100 \%$ passing the 35 mesh. Then a test without copper sulphate is prepared immediately to observe the effects on the solution. From these tests, it is observed that for gold dissolution, it is completed from six hours of leaching, showing complete solution for 12 hours, 24 hours and 48 hours.

The results of the four series shown in Table 5, where time keep constant at $24 \mathrm{~h}$, the $\mathrm{pH}$ of the test is 7-10 and the additions of ammonium hydroxide, copper sulfate and ammonium thiosulfate are shown.

Recoveries of the first fore tests decrease in values with respect to the III series, regarding silver show no appreciable difference, concerning gold recoveries is decreased according to this series.

Number 5 of the same series is corresponding to other mineral (sample B), in which high recovery of $\mathrm{Au}$ and $\mathrm{Ag}$ can be seen. The number 6 (sample $\mathrm{C}$ ) indicates otherwise the recovery of $\mathrm{Au}$ decreases while that silver increases less than expected and recovering only $69.3 \%$.

In the fifth series, leaching results show that the gold dissolves almost completely in the samples A and $B$, even when the particle size is coarser in the sample B, sample $\mathrm{C}$ in the recovery of gold and silver decreases as shown in Table 6. The assay results showed traces, so the recovery reservedly taken as $90 \%$ as atomic absorption in previous tests for zero gold is reported. 
Table 10 Summary of test results per sample SERIES VI.

\begin{tabular}{lllccc}
\hline \multirow{2}{*}{ Bottles } & $\begin{array}{l}\text { Particle size } \\
(\mathrm{mesh})\end{array}$ & $\mathrm{Au}$ & $\mathrm{Ag}$ & $\mathrm{Au}$ & \multicolumn{2}{c}{ Recovery $(\%)$} \\
\hline 1A & -100 & 0.0 & 0.0 & 100 & 100 \\
2A & -100 & 0.0 & 0.0 & 100 & 100 \\
3A & -100 & 0.0 & 0.0 & 100 & 100 \\
4A & -100 & 0.0 & 0.0 & 100 & 100 \\
1B & -35 & 0.5 & 29 & 89 & 77 \\
2B & -35 & 0.0 & 27 & 100 & 78 \\
3B & -35 & 0.7 & 26 & 85 & 79 \\
4B & -35 & 1.10 & 24 & 77 & 81 \\
5B & -35 & 0.40 & 15 & 91 & 88 \\
1C & -35 & 0.2 & 75 & 87 & 63 \\
2C & -35 & 0.27 & 82 & 83 & 60 \\
3C & -35 & 0.27 & 66 & 83 & 68 \\
5C & -35 & 0.45 & 77 & 71 & 66 \\
\hline
\end{tabular}

The results of the sixth series of tests that have different particle size, respecting the leaching conditions and varying time reveal certain assaying the dissolution of gold and silver. To clarify this point, the data obtained are summarized in Table 10.

\section{Conclusions}

Ores treated in this study belong to the Southern region of the state of Chihuahua, which would need to apply in ores mineralogically different.

The research for cyanidation lasted three months with a recovery of $37.2 \%$ for silver, for gold, appreciable results in the assay was not obtained by dry process. Tests with ammonium thiosulfate require less time and work with more confidence in handling the reagents, there was no difference in precipitating solutions for both leaching methods.

To perform the test with ammonium thiosulfate, it took into account the optimal particle size used in the cyanidation. Those are $100 \%$ to less than 100 mesh and a dilution 2: 1 .

The results obtained by atomic absorption showed a nearly complete recovery of gold, the solution of which is deduced to $100 \%$ of that in the ammonium thiosulfate solution. While the results for silver are inconsistent.

Regarding the $\mathrm{pH}$, it was maintained at baseline in
10 and the end at 7, from which the authors conclude that the $\mathrm{pH}$ is not a determining factor in the dissolution of gold and silver with ammonium thiosulfate.

Copper sulfate on the sample A does not showed appreciable change in the recovery of precious metals.

The chemical reagents added and doses do not show impact in increasing dissolution tests with ammonium thiosulfate.

The optimal time for ammonium thiosulfate leaching is in the range of 3 hours to 6 hours of treatment.

By varying the particle size, it was observed that the size is inconsequential as passing $100 \%$ through a 35 mesh recovery, which was similar to the $100 \%$ pass 100 mesh

As a general conclusion, it was noted that different sets of gold dissolution test was always higher than that of silver, with a time of less than cyanide agitation, as shown in Table 10.

It should be noted that the repeatability of the results are regardless of the analyst, analytical method and equipment used.

For the second stage of research tests at the pilot level, it is intend to establish the ongoing process contemplated with a high probability of replacing cyanide at low cost and with conventional infrastructure. 


\section{Ammonium Thiosulfate Ecological Viable Alternative to Replace Sodium Cyanide in Gold and Silver Dissolution Ores}

\section{References}

[1] Contreras Castro, D. 1967. Experimentation Minerals Gold and Silver for the Cyanidation Process. México, D.F: CFM.

[2] Delgado Alfaro, E., and Michel, D. 2011. "Ores Gold Leaching Using Thiosulphate: An Alternative Technology to Gold Ores Cyanidation.” Accessed February 20, 2014. http://documents.mx/documents/lixiviacion.html.

[3] Hernández, J. 2013. "Kinetic Study of the Leaching of Silver in the System $\mathrm{S}_{2} \mathrm{O}_{3}{ }^{2-}-\mathrm{O}_{2}-\mathrm{Cu}^{2+}$, Contained in Mining-Metallurgical Waste." Accessed February 21, 2014.

http://www.scielo.cl/scielo.php?pid=S0718-07642013000 $100007 \&$ script $=$ sci arttext.

[4] Genik-Sas-Berezowsky, R., Sefton V., and Gormely L. 1978. Recovery of Precious Metals from Metal Sulphides. US Patent 4,070,182 A, filed August 13,1976, and issued January 24, 1978.

[5] Kerley, B. 1981. Recovery of Precious Metals from
Difficult Ores. US Patent 4,269,622 A, filed December 28, 1979, and issues May 26, 1981.

[6] Kerley, J. 1983. Recovery of Precious Metals from Difficult Ores. US Patent 4,369,061 A, filed October 20, 1980, and issues January 18, 1983.

[7] Laurel Gómez, M. 2014. "Perspective of the Employment of Alternative Lixiviantes Agents to the Cyanide for the Recovery of Gold and Silver." CIPIMM. Accessed March 12, 2015. http://www.cipimm.co.cu/revista-info/ descargas/2-2014/13-RESE\%C3\%91A\%20pp.74-84.pdf.

[8] Melo Halmenschlager, P. 2015. "Leaching of Gold and Silver from Printed Circuit Board of Mobile Phoes." Metallurgy and Materials. Accessed April 16, 2015 http://www.redalyc.org/pdf/564/56438403008.pdf.

[9] Pérez, A., and Galaviz, H. 1987. Method for Recovery of Precious Metals from Difficult Ores with Copper-Ammonium Thiosulfate. US Patent 4654078 A, filed July 12, 1985, and issues March 31, 1987.

[10] Teijón Rivera José, M. 2006. Fundamentals of Structural Biochemistry. Madrid: Ed. Tébar. 